\title{
THE METABOLISM AND FATE OF TRITIATED THYMIDINE IN MAN * $\dagger$
}

\author{
By JOSEPH R. RUBINI, $\ddagger$ EUGENE P. CRONKITE, VICTOR P. BOND AND \\ T. M. FLIEDNER § \\ (From the Medical Research Center, Brookhaven National Laboratory, Upton, N. Y.)
}

(Submitted for publication December 9, 1959; accepted January 22, 1960)

The incorporation of thymidine (thymine deoxyriboside) into deoxyribonucleic acid (DNA) of proliferating cells has been studied in the past with various isotopic labels and biochemical techniques. Reichard and Estborn showed that thymidine- $\mathrm{N}^{15}$ was a specific precursor of DNA thymine in rats (1). Friedkin, Tilson, Roberts and Wood $(2,3)$ used thymidine-2- $\mathrm{C}^{14}$ to show that this compound was incorporated into DNA thymidine of proliferating embryo and animal tissues with negligible partition of radioactivity into other components of DNA or into ribonucleic acid.

The recent synthesis of tritium-labeled thymidine by Taylor, Woods and Hughes (4) has made available thymidine labeled with a nonexchangeable long-lived, low energy beta emitter $(0.018 \mathrm{Mev})$. Detection of this weak energy beta has been facilitated by the introduction of liquid scintillation spectrometers. Tritium-labeling of this DNA precursor has been further exploited in detecting newly formed DNA of single proliferating cells. The very low energy of the tritium $\beta$ [a maximum range in tissue of only $7 \mu$; half of the betas travel less than $1 \mu$ (5)] makes possible high-resolution autoradiograms of labeled cell nuclei. The water insolubility of DNA after cytological fixation is fortunate, since autoradiography carried out by usual stripping film technique requires aqueous solutions that remove soluble tritiated compounds.

Tritiated thymidine is being used in this laboratory to investigate cell turnover and dynamics of human and animal tissues studied both in vivo

\footnotetext{
* Published in abstract form in Clinical Research, April, 1958.

$\dagger$ This research was supported by the United States Atomic Energy Commission.

$\ddagger$ Present address: Radioisotope Service, Veterans Administration Hospital and The University of Texas Southwestern Medical School, Dallas, Texas.

§ Present address: Czerny-Krankenhaus für Strahlenbehandlung der Universität, Heidelberg, Germany.
}

and in vitro by serial autoradiographic evaluation of labeled cell populations (6-9). In the course of these in vivo investigations it became important to assess the availability time of tritiated thymidine for incorporation into DNA following rapid intravenous injection. It is essential for serial study of proliferating cell populations that the $\mathrm{H}^{3}$-thymidine label be available for incorporation into new DNA for only a small part of the DNA synthesis time, and that afterward there be no further label availability. This short availability time of $\mathrm{H}^{3}$-thymidine then permits study of the various components of the generation cycles (preand postmitotic rests, mitosis and DNA synthesis) by serial study of the appearance of labeled mitotic figures, the appearance of labeled nondividing cells and the decrease of labeling upon subsequent successive mitoses. From these data a kinetic analysis should determine the flow rate between compartments and the time spent in each state $(8,9)$.

The metabolic studies reported here indicate that the effective availability time for intravenously administered $\mathrm{H}^{3}$-thymidine is a matter of minutes. The metabolic fate of this tritium-labeled compound was examined by analyses of serial specimens of plasma, stool and urine as well as by evaluation of autoradiograms of tissues. These studies revealed that catabolism of some $\mathrm{H}^{3}$-thymidine to tritiated water (THO) as well as to nonvolatile tritiated compounds occurs. From the data to be presented here it appears that at least 50 per cent of injected $\mathrm{H}^{3}$-thymidine was retained in vivo and was presumably incorporated into new DNA of proliferating cells.

Recently Fink, Kline, Henderson and Fink (10), described a pathway of thymine degradation resulting in the formation of $\beta$-aminoisobutyric acid (BAIBA). BAIBA excretion following $\mathrm{H}^{3}$-thymidine injection was studied in these patients, and tritiated BAIBA was identified in the urine. 


\section{SUBJECTS}

Two patients with brain tumors, selected for this initial investigation, were judged to have short life expectancies and to be in hemopoietic equilibrium at the time of study. Pertinent clinical data are summarized below:

D.S. (BNL 8931-R), a 44 year old machinist, developed progressive neurological symptoms during a 3 month period. After neurological investigation, the patient underwent craniotomy and required ventricular drainage. Postoperatively he became comatose and was transferred to this hospital with the diagnosis of glioblastoma multiforme. The admission examination revealed a well developed but comatose and decerebrate man appearing in excellent nutritional status. Vital signs were normal; there were no papilledema and no nuchal rigidity. Skin turgor was excellent and there were no decubiti. The rest of the physical examination was unremarkable. Peripheral blood findings were as follows: hematocrit, 44 per cent; total leukocyte count 11,000 per cu $\mathrm{mm}$; normal differential; platelet counts approximately 300,000 per cu $\mathrm{mm}$. Bone marrow aspirates revealed normal marrow cell morphology and cell ratios. Urinalyses showed adequate concentration with traces of albumin; microscopic examination of the sediment revealed pyuria and bacilluria. The following determinations as well as blood counts were repeatedly normal during study period D.S. I and II (see below) : fasting blood sugar, serum sodium, potassium, chloride, carbon dioxide, uric acid, blood urea nitrogen and liver functions. Stools were guaiac negative. Chest X-rays and electrocardiograms were normal.

The patient received high caloric nasogastric feedings and adequate fluids. A Foley catheter was required to maintain urinary outflow. His hospital course was infrequently complicated by fever. Antibiotics were used briefly and only when indicated. The patient remained comatose during his remaining 6 months of life and it is noteworthy that no decubiti appeared. In spite of attempts to maintain his nutritional status there was a progressive and significant weight loss marked by loss of subcutaneous fat. Autopsy confirmed the presence of an invasive glioblastoma multiforme of the brain stem. Repeated intravenous injections of $\mathrm{H}^{3}$-thymidine were given, each followed by a study period during which $\mathrm{H}^{3}$ metabolism and distribution was assessed. Table I shows the amount of $\mathrm{H}^{3}$-thymidine injected at each study period. During study periods D.S. III through V the patient received tritiated thymidine because death appeared imminent. Each time, however, the patient rallied and returned to a more stable state.

W.S. (BNL 9113-R), the second patient, was a 65 year old retired motion picture projector operator who developed visual disturbances 2 months before neurosurgery. At operation a large cystic glioblastoma multiforme was subtotally removed. Postoperatively, he received two courses of irradiation to the tumor area. At admission to Brookhaven 9 months later, the patient was ambulatory and alert. He was well nourished and the vital signs were normal. Physical examination revealed residual left homonymous hemianopsia and left partial hemiplegia. All operative scars were well healed. The remainder of the physical examination was unremarkable. The hematocrit was 40 per cent and the leukocyte count was 4,000 per $\mathrm{cu} \mathrm{mm}$. The peripheral blood smear was normal and bone marrow aspirates revealed normal hematopoiesis. Urinalyses were normal as were determinations of blood urea nitrogen, uric acid and liver functions. Stools were guaiac negative. Chest $\mathrm{X}$-rays were unremarkable and the electrocardiogram was normal.

After a two month hospital stay during which time he remained afebrile and unchanged clinically, the patient received an injection of $\mathrm{H}^{3}$-thymidine and subsequently returned to his home; he died 4 months later. Autopsy was not performed. In Table I are shown data relevant to the $\mathrm{H}^{3}$-thymidine injection in this patient.

\section{METHODS}

1. $H^{3}$-thymidine. Thymine- $6 \mathrm{H}^{3}$-deoxyriboside, molecular weight 242 , was obtained ${ }^{1}$ in vials containing sterile $10 \mathrm{ml}$ pyrogen-free aqueous solutions of $1 \mathrm{mc}$ per ml. Specific activities varied initially from $0.208 \mathrm{c}$ to $1.9 \mathrm{c}$ per mmole. The compound was recrystallized with carrier thymidine and found free of impurities by paper chromatography.

2. $H^{3}$-thymidine injection. After control plasma and urine specimens were obtained, a rapid injection of $\mathrm{H}^{3}$ thymidine was made into the tubing of an intravenous drip and flushed promptly with saline. Timed heparinized or oxalated blood specimens were obtained without stasis from the opposite arm at frequent intervals during the first hour, then less frequently as is described in the data. Urine and plasma specimens were collected under mineral oil to reduce tritiated water (THO) exchange with air water vapor and were promptly frozen and stored until further processing could be done.

3. Liquid scintillation counting. Tritium activity was determined using a liquid scintillation spectrometer. ${ }^{2}$ The liquid counting system consisted of the sample dissolved in absolute ethanol and 0.3 per cent 2-(4-biphenyl)-5-phenyl-3, 4-oxadiazole (PBD) in xylene. The efficiency of this system for aqueous $\mathrm{H}^{3}$ counting was 10 per cent as determined by counting known $\mathrm{H}^{3}$ standards prepared similarly. One sample counted 25 times showed a mean of $4,985 \mathrm{cpm}$ with a standard error (11) of 42 . Groups of samples were counted with known $\mathrm{H}^{3}$ standards and small corrections were made for slight changes in efficiency on different days. New counting vials ${ }^{3}$ were used throughout and discarded after use.

4. THO determination (12). Urine or plasma aliquots were rapidly pipetted into size-matched $60 \times 15 \mathrm{~mm}$

${ }^{1}$ Schwarz Bioresearch, Inc., Mt. Vernon, N. Y.

2 Tricarb Liquid Scintillation Spectrometer, model 314, Packard Instrument Co., LaGrange, Ill., with automatic sample changer.

${ }^{3}$ Wheaton Glass Company, Millville, N. J. 
TABLE I

THO formation and nonvolatile $H^{3}$ excretion in the urine during the first day following $H^{3}$-thymidine injection in patients

\begin{tabular}{|c|c|c|c|c|c|c|c|c|c|}
\hline \multirow[t]{2}{*}{$\begin{array}{l}\text { Patient study } \\
\text { period }\end{array}$} & \multirow{2}{*}{$\begin{array}{l}\begin{array}{c}\text { Specific } \\
\text { activity }\end{array} \\
\text { c/mmole }\end{array}$} & \multicolumn{2}{|c|}{$\begin{array}{c}\mathrm{H}^{\mathbf{3}} \text {-thymidine } \\
\text { injected }\end{array}$} & \multirow{2}{*}{$\frac{\begin{array}{c}\text { Body } \\
\text { weight }\end{array}}{k g}$} & \multirow{2}{*}{$\begin{array}{c}\begin{array}{c}\text { Total body } \\
\text { water* }\end{array} \\
\%\end{array}$} & \multicolumn{2}{|c|}{$\underset{\text { formed }}{\text { Maximum THO }}$} & \multicolumn{2}{|c|}{$\begin{array}{l}\text { Urine nonvolatile } \\
\mathrm{H}^{2} \text { excreted }\end{array}$} \\
\hline & & $m c$ & $\mu c / g$ & & & $m c$ & $\%$ & $\mu c$ & $\%$ \\
\hline D.S. I & 0.208 & 9 & 0.14 & 66.7 & 52 & 2.16 & 24 & 117 & 1.3 \\
\hline D.S. II & 1.3 & 19 & 0.31 & 59.2 & 60 & 5.51 & 29 & 253 & 1.3 \\
\hline W.S. & 1.3 & 8.25 & 0.14 & 61.2 & 52 & 3.10 & 37.5 & 1,565 & 18.9 \\
\hline D.S. III & 1.3 & 10 & 0.18 & 55.8 & 65 & 6.02 & 60.2 & 660 & 6.6 \\
\hline D.S. IV & 1.3 & 10 & 0.19 & 52.9 & 65 & $1.99 \dagger$ & $19.9 \dagger$ & 638 & 6.4 \\
\hline D.S. V & 1.3 & 9 & 0.18 & 50.8 & 65 & 5.15 & 57.2 & $279 \dagger$ & $3.1 \dagger$ \\
\hline D.S. VI & 1.3 & 10 & 0.22 & $45.0^{*}$ & 65 & 6.43 & 64.3 & 783 & 7.8 \\
\hline
\end{tabular}

* Estimated.

† Incomplete sampling.

Petri dishes which were then sealed with tape. ${ }^{4}$ The sealed dishes were placed on a hot plate at low heat and the upper lids cooled by placing beakers containing a dry ice-acetone mixture upon them. The distilled water collected as ice on the under surface of the upper lids of the sealed containers. When sufficient ice had collected, the lower lids were replaced with unused lids, and after resealing, the dishes were inverted. After melting, $100 \mu 1$ samples of water were pipetted into counting vials containing $3 \mathrm{ml}$ ethanol and $12 \mathrm{ml}$ PBD-xylene. After capping and shaking, the vials containing colorless, clear solutions were counted. THO activity was expressed as cpm per $100 \mu \mathrm{l}$ water without correction for the nonaqueous portions of urine or plasma.

Air exposure was brief and resulted in no detectable loss by exchange with room water vapor. Six separate THO determinations on the same sample indicated a mean of $1,863 \mathrm{cpm}$ with a standard error of $22 \mathrm{cpm}$. Repeated fractional distillations of water from the same urine sample had the same THO activity. A similar experience has been reported by Cooper, Radin and Borden (13).

In calculating the maximum amount of $\mathrm{H}^{3}$-thymidine catabolized to THO following injection into the patient, the urine or plasma specimen with the highest THO activity was considered representative of $\mathrm{THO}$ activity distributed in total body water (TBW) at that time. TBW was estimated on the assumption that it is $\mathbf{5 2}$ per cent in normal men (14) and that weight loss with loss of subcutaneous fat would increase TBW. Estimates of TBW in the patients at the time of $\mathrm{H}^{3}$-thymidine injections are shown in Table I. In Patient D.S. residual THO activity from previous injections was subtracted. Maximum THO formed in $\mathrm{mc}$ from $\mathrm{H}^{3}$-thymidine injected was calculated as follows :

$\mathrm{A}=$ highest $\mathrm{THO}$ activity of plasma or urine, cpm per $100 \mu \mathrm{l} .10 \mathrm{~A}=\mathrm{cpm}$ per $\mathrm{ml} ; 100 \mathrm{~A}=\mathrm{dpm}$ per $\mathrm{ml}$ (at 10 per cent efficiency). $\mathrm{P}=$ estimated $\mathrm{TBW}$ in per cent. $\mathrm{W}=$ weight in $\mathrm{kg} ; 10^{3} \times \mathrm{W}=$ volume in $\mathrm{ml}$. $100 \mathrm{~A} \times$

4 Scotch no. 33 electrical tape.
$\mathrm{P} \times 10^{3} \mathrm{~W}=($ total $) \mathrm{dpm} ; \mathrm{dpm} \times 4.55 \times 10^{-10} \mathrm{mc}$ per $\mathrm{dpm}$ $=\mathrm{mc}(\mathrm{THO})$.

Daily plasma and urine THO activity was plotted on the log ordinate versus days, and the best resultant straight line was used to estimate the biological half-life of the THO.

5. Total $H^{3}$ activity. Total $\mathrm{H}^{3}$ activity was estimated by combining $100 \mu \mathrm{l}$ of plasma or urine with $3.4 \mathrm{ml}$ ethanol in a conical centrifuge tube. After capping and mixing, the tube was centrifuged briefly to separate the protein solids and chromogens. Three $\mathrm{ml}$ of the ethanol extract containing $\mathrm{H}^{3}$ compounds soluble in the ethanol mixture was removed and added to $12 \mathrm{ml} \mathrm{PBD}$-xylene in a counting vial for $\mathrm{H}^{3}$ counting. The activity obtained was corrected for the residual volume remaining in the centrifuge.tube and expressed therefore as cpm per 100 $\mu \mathrm{l}$ plasma or urine. There was no $\mathrm{H}^{3}$ activity in the insoluble ethanol-washed precipitate. Determination of total $\mathrm{H}^{3}$ activity of a prepared mixture of $\mathrm{H}^{3}$-thymidine in water and $\mathrm{H}^{3}$-thymidine in plasma gave identical results. In another preliminary experiment, $\mathrm{H}^{3}$-thymidine was found to be readily dialyzable from plasma. Six separate determinations of total $\mathrm{H}^{3}$ activity on the same plasma had a mean of $3,460 \mathrm{cpm}$ with a standard error of $20 \mathrm{cpm}$.

6. Nonvolatile $\mathrm{H}^{3}$ activity. Nonvolatile $\mathrm{H}^{3}$ activity represents the difference between total $\mathrm{H}^{3}$ activity and THO activity of the same sample. Plasma nonvolatile $\mathrm{H}^{3}$ activity was estimated from curves of total $\mathrm{H}^{3}$ activity and THO activity of the plasmas. In the case of urine specimens, nonvolatile $\mathrm{H}^{3}$ activity was always obtained by subtracting THO activity from total $\mathrm{H}^{3}$ activity of each sample. Urine nonvolatile $\mathrm{H}^{3}$ activity in $\mu \mathrm{c}$ was calculated as follows:

$\mathrm{A}=\mathrm{cpm}$ per $100 \mu \mathrm{l}$ nonvolatile $\mathrm{H}^{3}$ activity. $100 \mathrm{~A}=$ dpm per $\mathrm{ml}$ urine nonvolatile $\mathrm{H}^{3}$ activity. $\mathrm{V}=$ urine volume in ml. $\mathrm{V} \times 100 \mathrm{~A} \times 4.55 \times 10^{-7}=\mu \mathrm{c}$ excreted.

7. Autoradiography. Autoradiograms of bone marrow and white cell concentrates of peripheral blood were prepared as previously described (7).

8. Urinary $\beta$-aminoisobutyric acid. Urine aliquots were desalted by passage through Dowex- 2 columns, as 


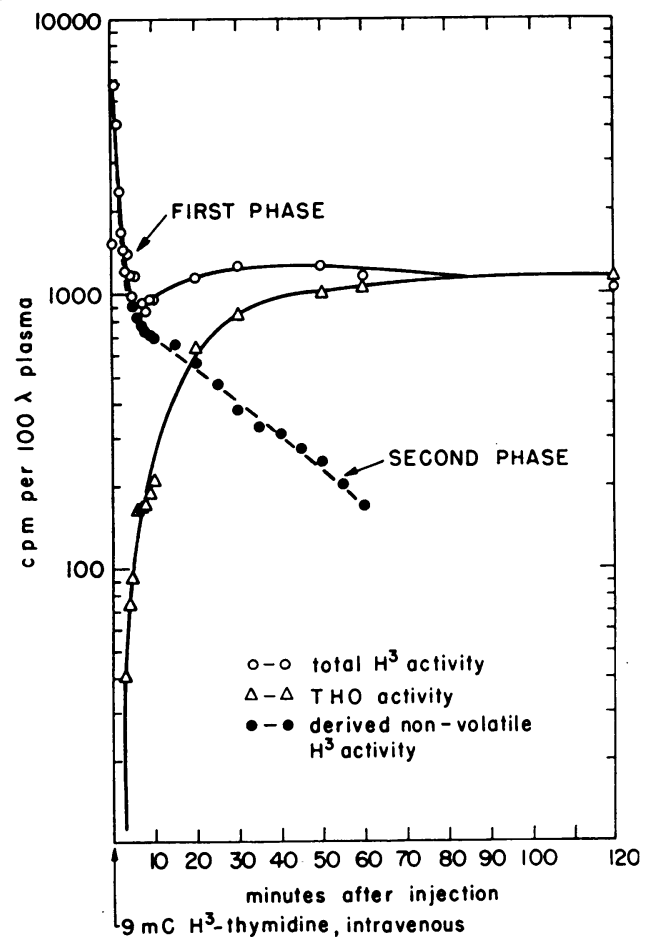

Fig. 1. Plasma tritium activity following intravenous $\mathrm{H}^{3}$-thymidine injection in Patient D.S. I.

described by Awapara and Sato (15). Two-dimensional chromatography of desalted urine fractions permitted identification of BAIBA and semiquantitative estimations of micromoles of BAIBA excreted per day as previously reported (16).

BAIBA spots as well as control areas from selected chromatograms were cut out, eluted with acidified water, and concentrated to $100 \mu 1$. These fractions were placed in counting vials with ethanol and PBD-xylene and the $\mathrm{H}^{3}$ activity was counted in the liquid scintillation spectrometer.

\section{RESULTS}

Plasma $\mathrm{H}^{3}$ activity following $\mathrm{H}^{3}$-thymidine injection rose to a maximum within one minute after injection and then declined precipitously. However, it should be pointed out that $\mathrm{H}^{3}$-thymidine was being lost simultaneously with mixing and maximal activity $(5,800 \mathrm{cpm}$ per $\mu \mathrm{l})$ was found at one minute after injection. If uniform mixing had occurred without loss from the plasma the maximum would have been about $60,000 \mathrm{cpm}$. Hence about 90 per cent of the injected activity was lost from the blood in the first minute. In all instances studied (D.S. I and II, as well as W.S.), the curves of plasma total $\mathrm{H}^{3}$ activity, nonvolatile $\mathrm{H}^{3}$ activity and THO activity were very similar. In Figure 1 the plasma $\mathrm{H}^{3}$ activity curves for Patient D.S. I are shown.

The first measurable phase of very rapid plasma clearance of nonvolatile $\mathrm{H}^{3}$ activity had identical slopes in all three instances. Ninety per cent of the observed initial maximal $\mathrm{H}^{3}$ activity of plasma was cleared within the next four minutes. In Figure 2 this rapid clearance phase in D.S. I is plotted to show two rapid components with half-times of 0.2 and 1.0 minute.

Partition studies of the plasma $\mathrm{H}^{3}$ activity between butanol and saturated ammonium sulfate during the first five minutes showed the greater part of the activity to be in butanol and thus characteristic of thymidine.

The clearance of $\mathrm{H}^{3}$-thymidine from plasma was associated with labeling of progenitor cells of the bone marrow. In the control autoradiograph, Figure 3a, performed on a bone marrow aspirated prior to $\mathrm{H}^{3}$-thymidine injection, the

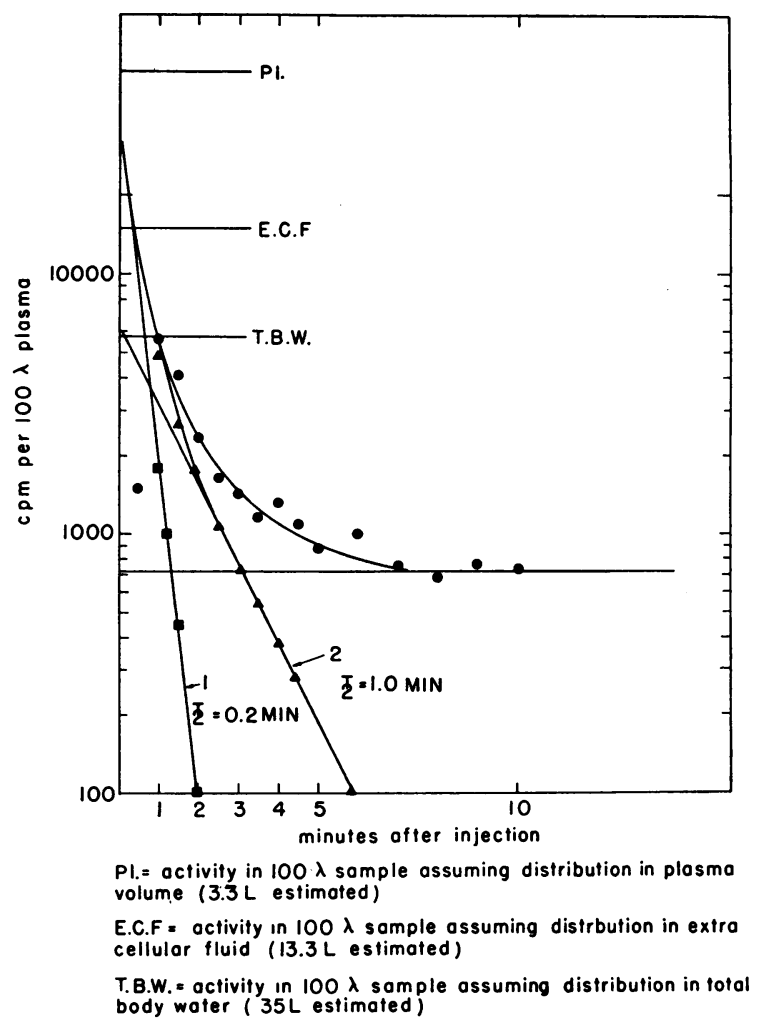

Fig. 2. Component analysis of the first phase of plasma nonvolatile $\mathrm{H}^{3}$ activity clearance in PaTIENT D.S. I. 


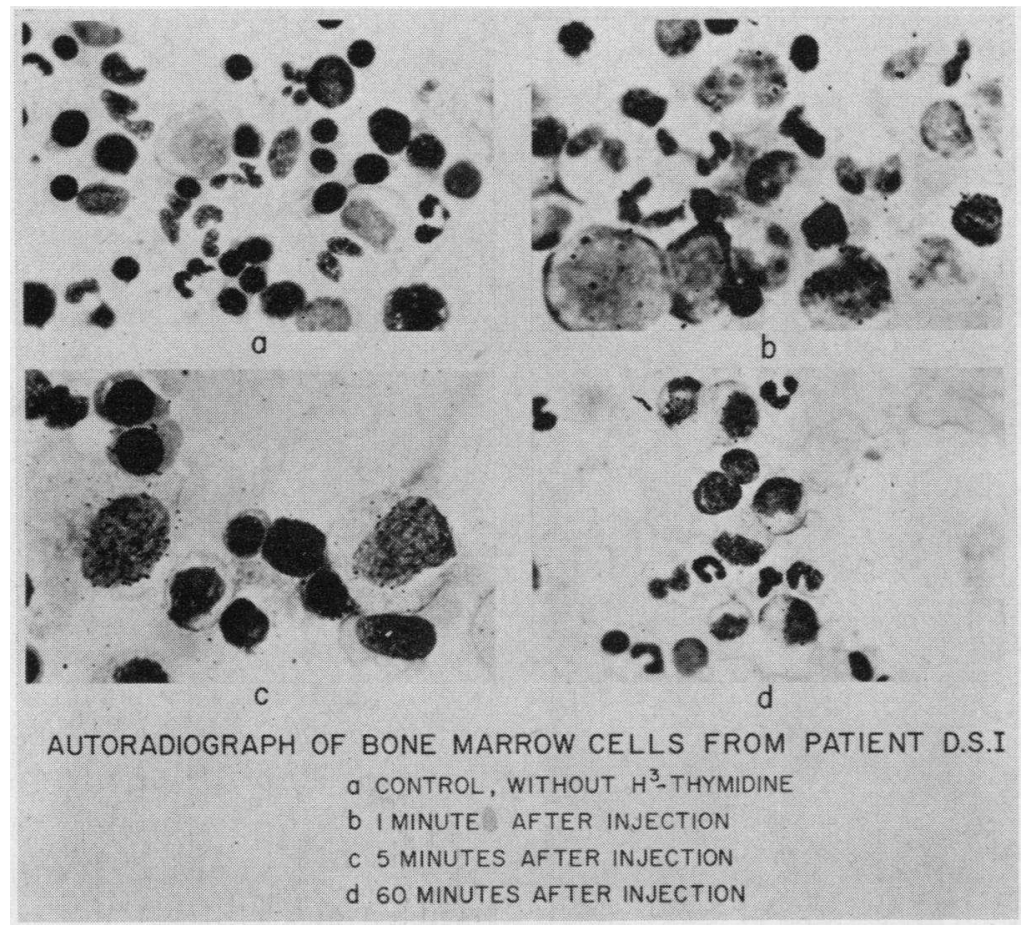

Fig. 3. Autoradiograph of bone marrow cells from Patient D.S. I.

negligible background is evident and no intranuclear labeling is seen. In contrast, the increasing degree of nuclear labeling is seen in Figures $3 \mathrm{~b}$ through 3d with time after injection. In. Figure $3 \mathrm{~b}$ is shown definite but light labeling at one minute after injection. At five minutes, Figure 3c, labeling of primitive cells by $\mathrm{H}^{3}$-thymidine incorporation is readily apparent. These labeled nuclei contain newly formed labeled desoxyribonucleic acid. The tritium label can be removed with desoxyribonuclease but not with ribonuclease (17). At one hour after injection, labeling is evident in erythrocytic and myelocytic cell lineages as is shown in Figure 3d. It is clear that there is a reciprocal relationship between the plasma clearance and incorporation of autoradiographically visible label into proliferating cells.

A second phase of plasma nonvolatile $\mathrm{H}^{3}$ activity in D.S. I is evident in Figure 1. In D.S. II this smaller component was identical and both had half-times of 25 minutes. Patient W.S., however, had low level plasma nonvolatile $\mathrm{H}^{3}$ activity for a considerably longer period of about 60 minutes. Plasma nonvolatile $\mathrm{H}^{3}$ activity during this second phase showed a greater $\mathrm{H}^{3}$ concentration in satu- rated ammonium sulfate than in butanol, indicating metabolism of $\mathrm{H}^{3}$-thymidine to more hydrophilic tritiated compounds.

In Figure 4 are shown the appearance curves for THO following $\mathrm{H}^{3}$-thymidine injection in D.S. I, II and in W.S. In Patient D.S., in both instances studied, THO appearance was prompt and revealed rapid catabolism of significant amounts of $\mathrm{H}^{3}$-thymidine to THO. At one hour after injection, at least 80 per cent of maximal THO activity had appeared. In Patient W.S. however, THO formation was somewhat slower. At one hour, less than 50 per cent of maximal THO had been evolved.

After the first hour there was a slight and gradual increase in plasma THO activity. Maximal THO activity of plasma was attained by 12 hours postinjection, a time sufficient for dilution and equilibration of newly formed THO with total body water. Estimates of total body water as per cent body weight of the patients, as well as the calculated amounts of $\mathrm{H}^{3}$-thymidine catabolized to THO, are recorded in Table I. It is seen from the table that at least 25 per cent of $\mathrm{H}^{3}$-thymidine was catabolized to THO. Correction for 


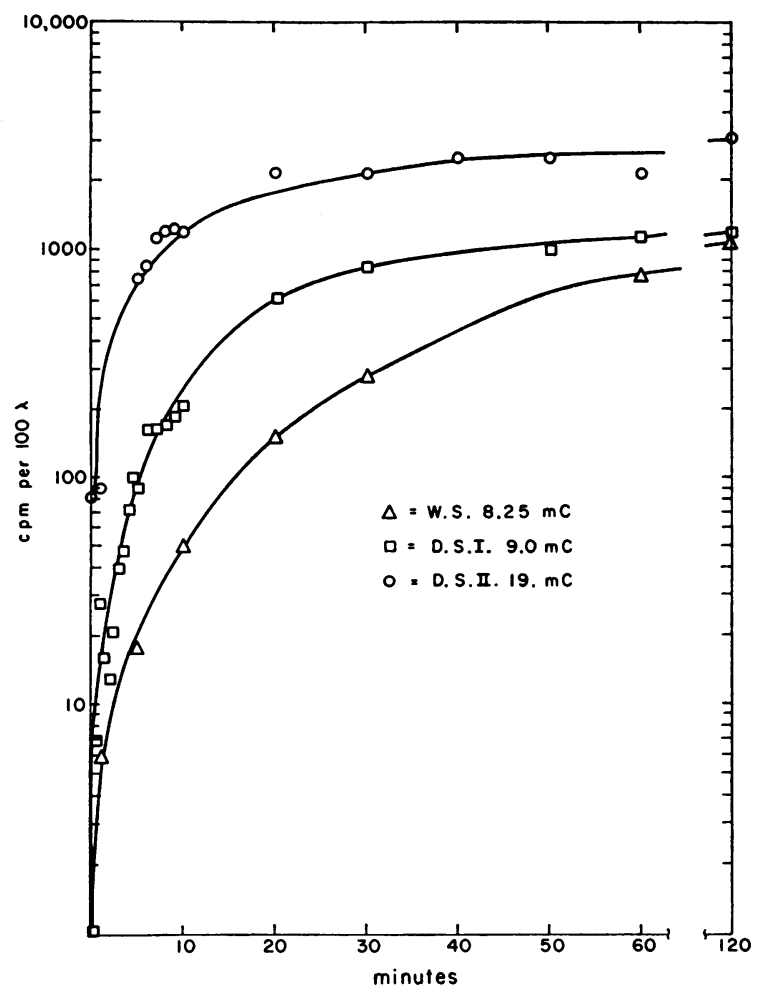

Fig. 4. Plasma THO appearance following $\mathrm{H}^{3}$ THYMIDINE INJECTION.

residual THO from previous injections was made where appropriate in the calculations.

Tritium water formed after $\mathrm{H}^{3}$-thymidine injection thus reached a maximum and then gradually declined over the ensuing days. When daily THO activities of plasmas and urines after injection were plotted on semilog paper, as shown in Figure 5, straight lines were obtained. The curves as shown are uncorrected for previous residual THO in D.S. V but this does not affect the slope. The biological half-life of the THO after injection, obtained from the slopes of the water curves shown in the figure, was from 7 to 12 days, compatible with the observed water balance. The absence of changes in slope or evident increase in THO concentration indicates that further large increments of THO were not formed after the initial maximum from degradation of labeled DNA or other sources. If continuous degradation of small amounts of $\mathrm{H}^{3}$-DNA occurs it is not detected.

Significant amounts of nonvolatile $\mathrm{H}^{3}$ activity were found in the urine only during the first 24 hours after $\mathrm{H}^{3}$-thymidine injection in these patients. In Figure 6, urine nonvolatile $\mathrm{H}^{3}$ activity excretion in $\mu \mathrm{c}$ per $\mathrm{ml}$ is plotted as a function of time after injection. In Patient D.S. significant amounts of urine nonvolatile $\mathrm{H}^{3}$ activity were excreted only during the first six hours after $\mathrm{H}^{3}$ thymidine injection. In Patient W.S. excretion was detectable in his urine for almost the entire first day. The nonvolatile $\mathrm{H}^{3}$ activity excreted during the first day is shown in Table I, as nonvolatile $\mathrm{H}^{3}$ activity in microcuries and as per cent of the initial injection of $\mathrm{H}^{3}$-thymidine.

Urine collected for the first hour was desalted and chromatographed. Examination with ultraviolet light failed to show absorption spots characteristic of intact pyrimidines. BAIBA spots were eluted from two-dimensional chromatograms of these early urines and counted for $\mathrm{H}^{3}$ activity. The presence of $\mathrm{H}^{3}$-BAIBA was established and appeared to be the major component of urine nonvolatile $\mathrm{H}^{3}$ activity. Patient W.S. regularly excreted unlabeled BAIBA in his urine in abnormally large amounts in contrast to D.S. whose urines contained essentially normal amounts of BAIBA.

Stools were passed infrequently by these patients. However, three stools from Patient D.S. passed during the first two weeks after injection of $\mathrm{H}^{3}$-thymidine were found to have $\mathrm{THO}$ activity equal to body water on the day passed. Attempts to find nonvolatile $\mathrm{H}^{3}$ activity in stools after homogenation and extraction with ethanol, butanol or water failed to reveal detectable amounts.

In Patient D.S. cerebrospinal fluid was available on Day 12 of D.S. II. It was found to have

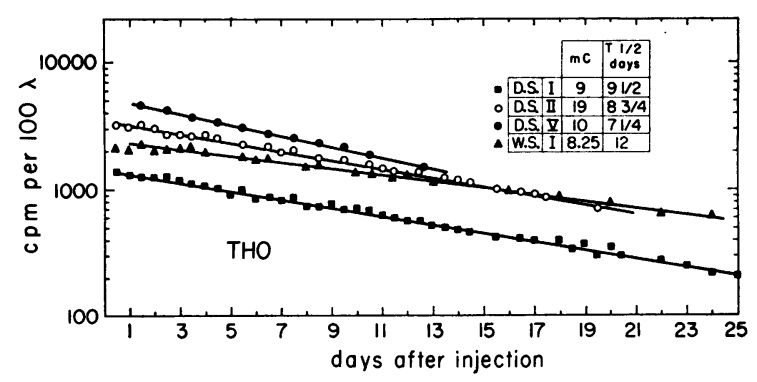

Fig. 5. Biological HALF-life of THO After $\mathrm{H}^{3}$ THYMIDINE INJECTION. 
THO activity equal to body water. No nonvolatile $\mathrm{H}^{3}$ activity was found.

Data obtained following the injection of $\mathrm{H}^{3}$ thymidine in D.S. III through VI are shown in Table I. In view of the critical condition of the patient on these occasions, samples obtained of plasma and urine were inadequate to evaluate fully the changes which occurred in $\mathrm{H}^{3}$ metabolism. Approximately 60 per cent of the $\mathrm{H}^{3}$-thymidine was catabolized to THO and there was also an increased excretion of nonvolatile $\mathrm{H}^{3}$ activity under these conditions. It appeared that less $\mathrm{H}^{3}$-thymidine was incorporated into DNA and more was diverted into other metabolic pathways.

\section{DISCUSSION}

The present metabolic studies after $\mathrm{H}^{3}$-thymidine administration in human beings yielded results similar to those of $\mathrm{H}^{3}$-thymidine in mice as reported by Hughes and colleagues (18). One hour following injection, about one-half of the administered tritiated thymidine is catabolized to THO, while the rest is presumably incorporated into DNA or converted to other compounds not identified.

These studies show that plasma is being cleared so rapidly in the first passage of the blood through the capillary bed that the entire amount injected is never uniformly mixed in plasma. At $1.5 \mathrm{~min}$ -

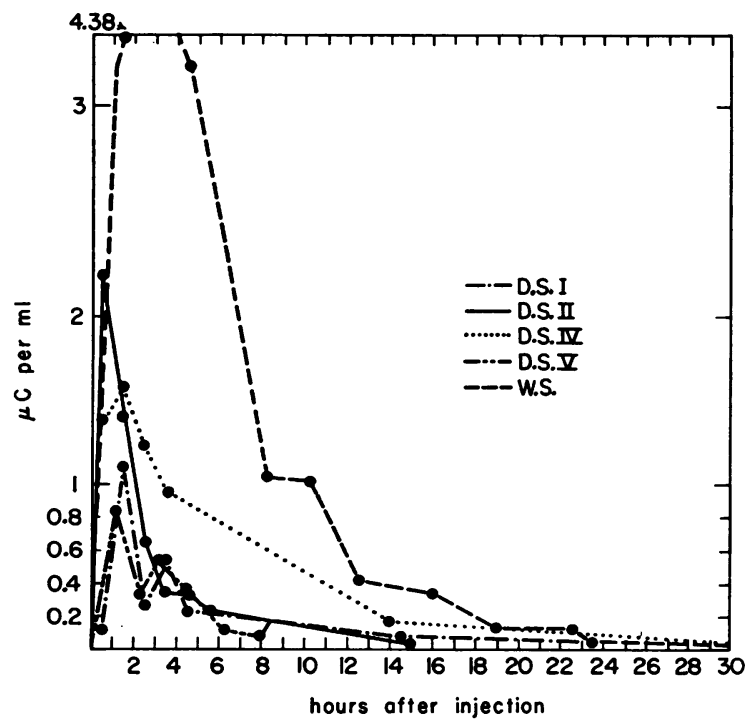

Fig. 6. URine nonvolatile $\mathrm{H}^{3}$ ACtivity excRetion.

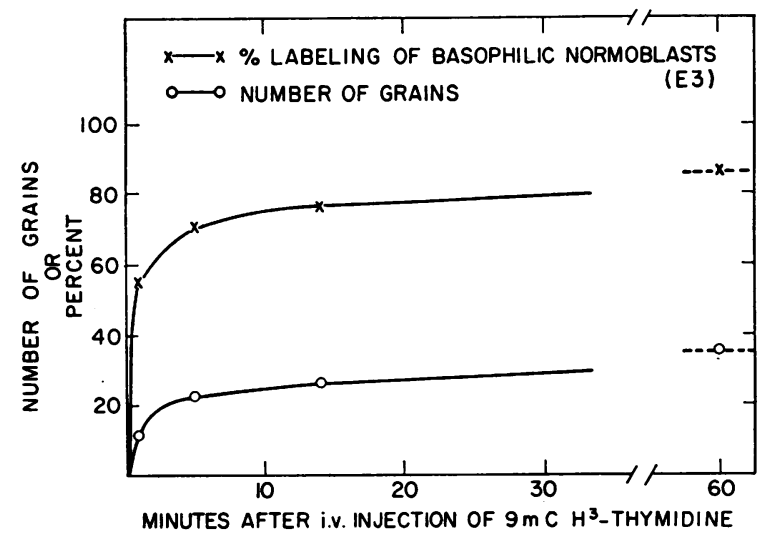

Fig. 7. LABELING OF BASOPHILIC NORMOBLASTS AFTER I.V. INJECTION OF 9 MC $\mathrm{H}^{3}$-THYMIDINE.

utes after injection, the plasma concentration corresponds to dilution in a volume as large as total body water. The rapid clearance phases after this apparent equilibrium value indicate that thymidine is being incorporated or degraded at very rapid rates. However it is not possible to correlate these specific clearance components with any definite anatomical or biochemical compartment such as incorporation into DNA of any specific proliferating cellular system or degradation in the liver. It is of interest, however, that the second component with a clearance rate of 1.5 to $2 \mathrm{~L}$ per minute may correspond to hepatic flow; however, this finding does not prove hepatic degradation. Further evidence for the possibility of prominent hepatic degradation has been published by Fink and associates (10). These workers have shown that liver slices actively catabolized thymine to BAIBA. Our butanol-ammonium-sulphate partition studies show that $\mathrm{H}^{3}$-thymidine is not present after the first ten minutes. The subsequent plasma nonvolatile $\mathrm{H}^{3}$ activity is due to the presence of more hydrophilic compounds, such as thymidilic acid (18) or products of thymine degradation such as BAIBA. The presence of $\mathrm{H}^{3}$-BAIBA in early urines after injection indicates that some of the $\mathrm{H}^{3}$-thymidine is rapidly hydrolyzed to $\mathrm{H}^{3}$ thymine and then to $\mathrm{H}^{3}$-BAIBA without having been incorporated into DNA. It is reasonable to implicate the liver as a major site of this catabolism with subsequent excretion of $\mathrm{H}^{3}$-BAIBA into the urine. Thus the injected $\mathrm{H}^{3}$-thymidine rapidly comes into equilibrium with the tissues and is either incorporated into new DNA or de- 
graded to THO and other substances which are not incorporated into DNA in significant amounts. The extremely rapid uptake of some of the $\mathrm{H}^{3}$-thymidine into new DNA was evident from positive autoradiograms of marrow cells obtained as early as one minute after injection (6).

Studies on the increasing average grain count of basophilic normoblasts confirm the rapid DNA synthesis and short availability time of the $\mathrm{H}^{3}$ thymidine for labeling, as is shown in Figure 7. Other cell lineages behave similarly. Hence, from these radiobiochemical and autoradiographic studies, the labeling process is seen to be essentially complete by about 60 minutes and most of the incorporation has occurred in the first 10 to 15 minutes after injection. At completion of DNA synthesis, the $\mathrm{H}^{3}$ label is assumed to remain in those cells for their life span and to be diluted only by mitosis. Since the effective availability time of $\mathrm{H}^{3}$-thymidine for incorporation into DNA is a small fraction of the time for DNA synthesis, then the ratio of labeled cells to total cells of a cell type approximates the ratio of the time for DNA synthesis to generation time of that cell lineage.

Radiation effects from $\mathrm{H}^{3}$-thymidine were not seen clinically in these patients. Higher doses of $\mathrm{H}^{3}$-thymidine will produce evident damage. Problems relating to $\mathrm{H}^{3}$-thymidine dosimetry and radiation effects have been discussed by Johnson and Cronkite (19) and by Hughes and associates (20) elsewhere.

When $\mathrm{H}^{3}$-thymidine of increasing specific activities was injected, as shown in Table I, essentially similar curves of plasma clearance during the first hour were obtained; this suggests that $\mathrm{H}^{3}$-thymidine was handled as if it were a tracer. Even in a patient who received only $3 \mathrm{mc}$ of $\mathrm{H}^{3}-$ thymidine (21), the plasma clearance was identical with that resulting from 9 and $19 \mathrm{mc}$. Also, the per cent of THO catabolized from $\mathrm{H}^{3}$-thymidine in D.S. I, II and W.S. is seen to be independent of the amount of $\mathrm{H}^{3}$-thymidine administered and further supports the view that $\mathrm{H}^{3}$-thymidine behaves as a tracer.

There is a striking increase in THO formation and a concurrent rise in urine nonvolatile $\mathrm{H}^{3}$ activity excretion from $\mathrm{H}^{3}$-thymidine injection in D.S. III through VI. During these periods the patient was markedly cachetic and it might be postulated that total DNA synthesis was reduced either by a change in cell turnover rate or by a decrease in the DNA synthesizing cell mass. Bone marrow autoradiographs during these intervals showed the usual labeling. In any event, during these circumstances more $\mathrm{THO}$ was produced from the injected $\mathrm{H}^{3}$-thymidine. Accordingly, it appears that the fraction of thymidine not incorporated into DNA is degraded through the steps which produce $\mathrm{THO}$ and nonvolatile tritiated compounds. This concept is supported by the fact that reduction in the mass of DNA synthesizing tissues by whole body irradiation in rats and guinea pigs (22) results in catabolism of a larger proportion of injected $\mathrm{H}^{3}$-thymidine to THO and increased excretion of nonvolatile $\mathrm{H}^{3}$ activity.

In Patient W.S. considerably greater amounts of urine nonvolatile tritium activity were excreted during the first day after $\mathrm{H}^{3}$-thymidine injection than were excreted in D.S. I and II. The main component of this urine nonvolatile $\mathrm{H}^{3}$ activity was $\mathrm{H}^{3}$-BAIBA. Patient W.S. had been excreting approximately $500 \mu$ moles of BAIBA in his urine daily before any $\mathrm{H}^{3}$-thymidine injection. This is distinctly above the usual normal levels of BAIBA excretion (16). The greater amounts of $\mathrm{H}^{3}$-BAIBA excreted by Patient W.S. compared with D.S. I and II may be related to his greater endogenous BAIBA output.

The absence of detectable amounts of nonvolatile tritiated compounds in stools suggests that the labeled gastrointestinal cells, which were subsequently sloughed and degraded in the intestinal lumen, liberated tritiated compounds which were reabsorbed. Since there were no significant perturbations in the turnover of body water, the amount of the labeled materials degraded, reabsorbed, and converted to tritiated water was too small to be detected after dilution in total body water. Unpublished studies (22) have shown that $\mathrm{H}^{3}$-labeled thymidine is absorbed after oral administration in animals and results in labeled cells with the greatest intensity in the gastrointestinal mucosa. Wilson and Wilson (23) have shown that thymidylic acid can be hydrolyzed to thymidine in the gut and subsequently absorbed. From our study and theirs it is reason- 
able to assume that the hydrolyzed products of labeled DNA are absorbed. This is consistent with the absence of nonvolatile $\mathrm{H}^{3}$ activity in the stools. The amount of $\mathrm{H}^{3}$-thymidine liberated from the degraded intestinal DNA is small and when absorbed, is diluted in total body water and subsequently excreted. It is not surprising then that increases in the urinary nonvolatile $\mathrm{H}^{3}$ activity were not found. However, the reabsorption of $\mathrm{H}^{3}$-thymidine would continue to provide labeling material over a long period of time. How much this may perturb the apparent turnover of labeled proliferating cellular systems in the body is not clear. However, it is clear that this possibility must be considered in all cases of autoradiographic or labeled purine-pyrimidine turnover studies. Reutilization of DNA or a long-lived cell population has been proposed by Ottesen (24) and Hamilton (25). However, in our opinion, based on calculations, this is probably not a serious problem because of the great dilution.

\section{SUMMARY}

1. The metabolism and fate of tritiated thymidine were studied in two patients in hemopoietic equilibrium.

2. Plasma clearance of $\mathrm{H}^{3}$-thymidine commences in the first circulation time and becomes exponential following apparent equilibrium with total body water. Two components - with half-times of 0.2 minute and 1.0 minute were identified and discussed.

3. The rapid plasma clearance of $\mathrm{H}^{3}$-thymidine was associated with incorporation of this compound into newly formed DNA of proliferating cells as early as one minute after injection.

4. Labeling of proliferative cells of the bone marrow was nearly complete within ten minutes after injection, and thereafter the label appeared to remain in these cells or their progeny for their life span, diluted only by successive mitoses.

5. This short availability time of intravenous $\mathrm{H}^{3}$-thymidine simplifies the analyses of the time parameters of labeled proliferating cell populations.

6. About one-third of the $\mathrm{H}^{3}$-thymidine was catabolized to THO within a few hours after injection.

7. Small amounts of urine nonvolatile $\mathrm{H}^{3}$ activity were excreted in the urine during the first day after injection. $\mathrm{H}^{3}-\beta$-aminoisobutyric acid was identified in these urines as a catabolic product of $\mathrm{H}^{3}$-thymidine.

8. Degradation and possible reutilization of the $\mathrm{H}^{3}$ label is discussed.

9. Severe malnutrition resulted in greater degradation of $\mathrm{H}^{3}$-thymidine to $\mathrm{THO}$ and urine nonvolatile $\mathrm{H}^{3}$ activity.

\section{REFERENCES}

1. Reichard, P., and Estborn, B. Utilization of desoxyribosides in the synthesis of polynucleotides. $\mathrm{J}$. biol. Chem. 1951, 188, 839.

2. Friedkin, M., Tilson, D., and Roberts, D. Studies of deoxyribonucleic acid biosynthesis in embryonic tissues with thymidine- $\mathrm{C}^{14}$. J. biol. Chem. 1956, 220, 627.

3. Friedkin, M., and Wood, H. IV. Utilization of thymidine- $\mathrm{C}^{14}$ by bone marrow cells and isolated thymus nuclei. J. biol. Chem. 1956, 220, 639.

4. Taylor, J. H., Woods, P. S., and Hughes, W. L. The organization and duplication of chromosomes as revealed by autoradiographic studies using tritium-labeled thymidine. Proc. nat. Acad. Sci. (Wash.) 1957, 43, 122.

5. Robertson, J. S., and Hughes, W. L. Intra-nuclear irradiation with tritium labeled thymidine. Proc. First Nat. Biophys. Conf. New Haven, Yale Univ. Press, 1959, pp. 278-283.

6. Cronkite, E. P., Bond, V. P., Fliedner, T. M., and Rubini, J. R. The use of tritiated thymidine in the study of DNA synthesis and cell turnover in hemopoietic tissues. Lab. Invest. 1959, 8, 263.

7. Bond, V. P., Fliedner, T. M., Cronkite, E. P., Rubini, J. R., Brecher, G., and Schork, P. K. Proliferative potentials of bone marrow and blood cells studied by in vitro uptake of $\mathrm{H}^{3}$-thymidine. Acta haemat. (Basel) 1959, 21, 1.

8. Cronkite, E. P., Fliedner, T. M., Bond, V. P., and Robertson, J. S. Anatomic and physiologic facts and hypotheses about hemopoietic proliferating systems in The Kinetics of Cellular Proliferation, Frederick Stohlman, Jr., Ed. New York, Grune and Stratton, 1959, p. 1.

9. Bond, V. P., Fliedner, T. M., Cronkite, E. P., Rubini, J. R., and Robertson, J. S. Cell turnover in blood and blood-forming tissues studied with tritiated thymidine in The Kinetics of Cellular Proliferation, Frederick Stohlman, Jr., Ed. New York, Grune and Stratton, 1959, p. 188.

10. Fink, K., Cline, R. E., Henderson, R. B., and Fink, R. M. Metabolism of thymine (methyl-C $\mathrm{C}^{14}$ or $-2-C^{14}$ ) by rat liver in vitro. J. biol. Chem. 1956, $221,425$.

11. Hill, A. B. Principles of Medical Statistics, 5th ed. New York, Oxford Univ. Press, 1952, p. 116. 
12. Ussing, H., and Wernstedt, A. A distillation device for small water samples. Skand. Arch. Physiol. 1940, 83, 169.

13. Cooper, J. A., Radin, N. S., and Borden, C. A new technique for simultaneous estimation of total body water and total exchangeable body sodium using radioactive tracers. The results in 13 normal men. J. Lab. clin. Med. 1958, 52, 129.

14. Beierwaltes, W., Johnson, P. C., and Solari, A. J. Clinical Use of Radioisotopes. Philadelphia, W. B. Saunders, 1957, p. 308.

15. Awapara, J., and Sato, Y. Paper chromatography of urinary amino acids. Clin. chim. Acta 1956, 1, 75.

16. Rubini, J. R., Cronkite, E. P., Bond, V. P., and Fliedner, T. M. Urinary excretion of beta aminoisobutyric acid (BAIBA) in irradiated human beings. Proc. Soc. exp. Biol. (N. Y.) 1959, 100, 130.

17. Plaut, W., and Sagan, L. A. Incorporation of thymidine in the cytoplasm of Amoeba proteus. J. biophys. biochem. Cytol. 1958, 4, 843.

18. Hughes, W. L., Bond, V. P., Brecher, G., Cronkite, E. P., Painter, R. B., Quastler, H., and Sherman, F. G. Cellular proliferation in the mouse as re- vealed by autoradiography with tritiated thymidine. Proc. nat. Acad. Sci. (Wash.) 1958, 44, 476.

19. Johnson, H. A., and Cronkite, E. P. The effect of tritiated thymidine on mouse spermatogonia. Radiat. Res. 1959, 11, 825.

20. Hughes, W. L., Robertson, J. S., Hamilton, L. D., Plaut, W., Cronkite, E. P., Craddock, C. G., Lamerton, L., Patt, H. M., and Bond, V. P. Discussion of radiation effects of cellular labels in The $\mathrm{Ki}$ netics of Cellular Proliferation, Frederick Stohlman, Jr., Ed. New York, Grune and Stratton, 1959, p. 135.

21. Rubini, J. R., and Cronkite, E. P. Unpublished observations.

22. Rubini, J. R., Wood, L., and Cronkite, E. P. To be published.

23. Wilson, T. H., and Wilson, D. W. Studies in vitro of digestion and absorption of pyrimidine nucleotides by the intestine. J. biol. Chem. 1958, 233, 1544.

24. Ottesen, J. On the age of human white cells in peripheral blood. Acta physiol. scand. 1954, 32, 75.

25. Hamilton, L. D. Control of lymphocyte production in Homeostatic Mechanisms. Brookhaven Nat. Lab. Symposia in Biol. 1957, no. 10, p. 52. 